\title{
The Profession's Role in Meeting its Historical Mission to Serve Vulnerable Populations
}

\author{
Dorcas Davis Bowles \\ June Gary Hopps
}

\begin{abstract}
This article provides an historical account of how the profession of social work met or failed to meet its mission in the provision of services to those who were poor, oppressed, and vulnerable to societal injustices from the mid-twentieth century, including the turbulent Civil Rights Era, to the early twenty-first century. The profession's growth and expansion and the challenge of mediating resistance to change are highlighted based on eyewitness accounts.
\end{abstract}

Keywords: Professional mission, CSWE standards, civil rights era, poverty, race, injustice, social work theories, women, people of color, sexual orientation and gender expression

In 1903, W. E. B. DuBois, one of the first writers to speak of oppression based on skin color stated, "The problem of the twentieth century is the problem of the color line the relation of the darker to the lighter races of men in Asia and Africa, in America and the islands of the sea" ( $p$ 16). Forty years later, Gunnar Myrdal was commissioned by the Carnegie Corporation to study race relations in the United States. Myrdal painstakingly detailed obstacles to full participation in American society that Negroes faced which he saw as a white man's problem. He articulated that the race problem in the United States presented a great dilemma that, if not resolved, threatened the ultimate success of the country's democratic experiment (Myrdal, 1944). Some thirty years ago in an editorial entitled Oppression Based on Color, Hopps (1982) stated that people of color face a pervasive kind of oppression and discrimination because of racial stereotypes associated with and indelibly marked by the color of their skin. Although many forms of exclusion and discrimination exist in this country, none is so deeply rooted, persistent, and intractable as that based on color.

Do these statements on race, over many years, continue to explain why certain societal conditions have not been improved despite greater national wealth and power? Does the claim by other groups - women, gays and lesbians, physically and mentally challenged, and at times even "white males" - minimize the challenge faced by "traditionally oppressed groups?" The geopolitical landscape is one that makes it attractive to be disadvantaged, even when the term is elusive and thus hard to define. For example, in the last presidential election, several candidates for the Republican presidential nomination described their "disadvantaged heritage." As compelling as those stories were, none of them had to face the abject racism with which the democratic candidate and sitting President had to live. Secret Service protection to Presidential candidate Obama began after the Senator received a death threat in 2007, when he was

Dorcas Davis Bowles, Ed.D., MSW, is a Distinguished Scholar of Social Work in the Department of Social Work and Human Services at Kennesaw State University in Kennesaw, GA. June Gary Hopps, Ph.D., MSW, is the Thomas M. Parnham Professor of Family and Children Studies in the School of Social Work at the University of Georgia in Athens, GA. The authors wish to thank Dr. Obie Clayton, Asa Edmund Ware Distinguished Professor and Chair, Department of Sociology and Criminal Justice at Clark University for his critique of the article.

Copyright (C) 2014 Advances in Social Work Vol. 15 No. 1 (Spring 2014), 1-20 
still serving as the Junior Senator of Illinois. This marked the first time that a presidential candidate received Secret Service protection before being nominated by his party (Obama placed under secret service protection (Friedman \& Maggs, 2008). The increased number of death threats and subsequent need for additional security was unprecedented in American presidential campaigns.

Social ethicist Daniel Maguire (1980) provided a framework for determining which groups are so disadvantaged that they need preference. He offered the following conditions: "(1) no alternatives to enforced preferences are available; (2) prejudice against the group has reached the level of depersonalization; (3) bias against the group is not private or narrowly localized but is rather entrenched in the culture and distributive systems of the society; and (4) the members of the victim groups are visible and thus lack an avenue of escape from their disempowerment" (Maguire, 1980, pp. 129-30, as cited in Hopps, 1982, p. 3). A report compiled by the Transnational Racial Justice Initiative (2001) concluded that the government has not taken "special and concrete measures to ensure the adequate development and protection of certain racial groups (Article II) (2) despite a preponderance of evidence of racism from both non-governmental organizations and governmental agencies. There are many documented examples of bias, racial discrimination and disparate racial impact in a wide range of policy arenas. There has been both governmental and private opposition to nearly every measure that would reduce white privilege and create greater development and advantage for disenfranchised racial groups" (p. 12).

Within the national context on race noted above, our task in this paper is to highlight the profession's role in the preparation of practitioners in the delivery of services as well as how the field has historically delivered services to people of color and vulnerable populations. Our observations are drawn from our eye witness accounts from the latter part of the twentieth century, particularly from the 1960s to the 1980s. Our connection to the field spans more than four decades covering a period when we were considered Colored, Negro, Black, Afro-American or African American. We were children of "race women" - those women who advocated the "uplift" of the race in the early $20^{\text {th }}$ century and who were determined that conditions that emerged from enslavement - overt racism and economic deprivation -- needed to be challenged. They had a deep awareness of the liberating role of education, the need to nurture strong families and to build caring communities. Our fathers (and grandfathers) were family and community oriented and subscribed to the values of education, strong work ethic, business orientation, and civil rights advances. During our elementary and high school years, we lived under the 1896 Supreme Court Decision of Plessy v. Ferguson which upheld the legality of separate but legal and where "Jim Crow Laws" were treated as legal. We were young students when, on May 14, 1954, the Supreme Court concluded that in the field of education, the doctrine of separate but equal had no place, that separate educational facilities are inherently unequal. In celebration of the Brown v. Board of Education decision, the choirs sang and the bells rang out in segregated churches, notably the strongest institution, aside from the family, in the Black community (Clayton, 1996). School children, even from poorly equipped schools, knew about the Warren Court and that it had spoken. No, "Colored people" felt that God had spoken! 
We were arrested as students at Tuskegee Institute and Spelman College and were moving into the profession during the Civil Rights struggle for freedom and equality in the 1960s. We witnessed far too many deaths of both Blacks and Whites who fought for justice and spoke out for civil rights:

- June 12, 1963 - Murder of Medgar Evers, a Black civil rights activist in Jackson, Mississippi, in the driveway of his home - by a member of the White Citizens Council.

- September 15, 1963 - Mass Murder of Four Black girls (Addie Mae Collins, age 14; Cynthia Wesley, age 14; Carole Robertson, age 14 and Denise McNair, age 11) by a bomb placed under the steps at the Sixteenth Street Baptist Church in Birmingham, Alabama while they were attending Sunday school classes.

- November 22, 1963 - The assassination of John Fitzgerald Kennedy, the $35^{\text {th }}$ President of the United States in Dallas, Texas.

- June 21, 1964 - Murder in Nashoba County Mississippi of one Black and two white Civil Rights Workers (James Cheney, Andrew Goodman, and Michael Schwerner) by members of the Mississippi White Knights of the Ku Klux Klan as they were driving to register Blacks to vote as part of the "Freedom Summer" campaign.

- February 18, 1965 - Shooting of Jimmy Lee Jackson, a Black civil rights activist, from Marion, Alabama by an Alabama State Trooper when he joined a group of African Americans who were protesting the jailing of a Southern Christian Leadership Conference Official. Jackson died on February 26, 1965 and on March 3, 1965 - Dr. King eulogized Jimmy Lee Jackson and called for a March from Selma to Montgomery to protest Jackson's death and advocate for voting rights. Dr. King publicly admonished President Lyndon Johnson, asking why the government could spend millions defending democracy in South Vietnam, but not do the same for its own U.S. citizens. It was at this time that King began to link the civil rights movement with the anti-Vietnam war movement.

- February 26, 1965 - Malcolm X was assassinated after repudiating the Nation of Islam and its teachings by three of its Black members. He was preparing to address the organization of Afro-American Unity in New York City at Manhattan's Audubon Ballroom.

- March 7, 1965 - Attempted Selma to Montgomery March - known as "Bloody Sunday." Demonstrators, including U.S. Congressman John Lewis, were brutally beaten, when they attempted to cross the Edmond Pettus Bridge. This event prompted federal lawmakers to pass the 1965 Voting Rights Act.

- March 21-25, 1965 - Demonstrators completed the Selma to Montgomery, Alabama march protected by the Alabama National Guard under federal control. 
- March 25, 1965 - Murder of Mrs. Viola Liuzzo, a white civil rights activist from Detroit Michigan by Ku Klux Klan members on the last night of the Selma to Montgomery March while transporting students from Historically Black Colleges and Universities and other marchers to their homes after the march. One of the Klansman in the car, from which the shots were fired, was a Federal Bureau of Investigation (FBI) informant.

- April 4, 1968 - The assassination of Dr. Martin Luther King, Jr., prominent leader in the advancement of civil rights, on the balcony of the Lorraine Hotel, Memphis Tennessee as he was preparing to march for Sanitation Workers.

- June 5, 1968 - The assassination of Senator Robert Kennedy (D. N.Y.), brother of the assassinated President John F. Kennedy, during the campaign season for the U. S. Presidential election, at the Ambassador Hotel in Los Angeles, CA.

We were witnesses to all of the above murders and assassinations and indeed many more. We, together with other Americans, experienced trauma as we mourned and attempted to understand and deal with these losses. Writing about this time frame and these losses for this paper reactivates the stress and pain, and even so we have no choice but to move on. We have seen, during the autumn of our professional life, the election (2008) and re-election (2012) and twice inaugurated first African American President, Barack Obama, something neither of us thought would occur during our lifetime.

\section{Societal Turbulence and the Profession's Move to Public Programs}

In the course of the twentieth century, the country flirted with progressivism, was impacted by World War I, the boom of the "roaring twenties" and economic chaos of the 1930s, enacted Social Security and other legislation as a hedge against financial insecurity and, rebuilt the economy during and after World War II, only to "discover" real poverty in the 1960s. In the 1960s, 1970s and 1980s the rights of colored people, women, gay, lesbian, transgender individuals and physically and mentally challenged were acknowledged. At this time, new immigrants as well as traditionally oppressed groups fight for a voice and recognition but the struggle for affirmative change continues.

The profession, since its inception, seems to have been challenged by a "push-pull" or ambivalence vis-a-vis power and powerlessness, wealth and inequality, and social control and benevolence. Prior to the Great Depression, services were delivered primarily through private auspices and largely to urban populations. The Great Depression, when at least a quarter of the population was unemployed and therefore poor, required massive intervention and changed the face of the profession. The Social Security Act was enacted as the nation's response to economic distress that affected so many. The economic loss had to be managed by many and so was the case with our own families: Farm assets and income, wages from labor, college scholarships; and the beginning ideological shift from the GOP (Lincoln's party or Hoover's Party?) to FDR. So we learned about the "great" democratic president who tried to help "our people, colored people." We knew about Eleanor Roosevelt, the First Lady, and respected her because she respected Mary McCleod Bethune, the great "colored" matriarch who founded Bethune-Cookman College and served as advisor to President Franklin D. Roosevelt. 
The New Deal changed the social welfare landscape, making services and benefits available to greater numbers of needful people including rural people and eventually people of color. Initially, Social Security programs followed the general societal model of racial discrimination. The social insurance aspects of Social Security were related to employment and early on, those in marginal, low-wage work settings, were excluded, including domestic workers, farm laborers, and restaurant and hotel workers, and a large number of these groups were Negroes. The profession was not initially enamored by the New Deal and its sweeping, undergirding ideological shift where major new resources (money, employment opportunities, and legislative clout) would be centered in the public domain, away from traditional private auspices.

World War II, which pulled the country out of the Depression, helped usher social work's movement to the mental health domain where there was emphasis on Freudian psychological theories which was referred to as casework (i.e., interventions with individuals and families, case by case). These theories placed the focus on the individual (Garrett, 1942; Hollis, 1949; Perlman, 1979). However, from the profession's beginning, there was scant attention given to people of color - Native Americans, African Americans, Puerto Ricans, and Mexicans. Similarly, little attention was given to poor southern whites and so called "hill people." The Mental Hygiene Movement prevailed; casework became king, or perhaps queen since the profession is predominantly female.

From the 1920s to the 1950s, social casework focused on the person in the context of his/her environment, and the therapeutic relationship between the social worker and the client was seen as key to facilitating change. Warmth, caring, genuineness, a nonjudgmental attitude, and empathy, among other qualities, were seen as "the soul of casework" (Biester, 1957) and as the "heart" of the helping profession (Garrett, 1942; Hollis, 1965; Perlman, 1979). In seeking a language to understand behaviors, social workers turned to Freud's theories of development which offered them terms such as resistance, transference and counter-transference. With the emergence of ego psychology during the late $50 \mathrm{~s}$, social workers found the concepts ego functions, defense mechanisms, and adaptation useful language in their work with clients (Erikson, 1950; Freud, 1936; Hartmann, 1958; Parad, 1958; Parad \& Miller, 1963).

Cultural values, economics, and public policy are inextricably linked aspects of the human experience. Hence, public and private policies can encourage or discourage behavior. The 1960s ushered in great social, cultural, and economic upheavals that had a profound impact on marriage and family among African Americans. Shifting occupational structures (from manufacturing to services), stagnating real wages, and the declining relative demand for low-skilled labor undermined the economic status of many and especially African Americans. Welfare policies that focused on helping mothers and children, to the exclusion of fathers, had the practical effect of keeping or driving men out of the household. Housing discrimination that facilitated the movement of whites out of the city while hampering the mobility of African Americans, the increasing suburbanization of employment, inadequate urban school systems, and the growing incarceration of African American men, played crucial roles in undercutting opportunities for African Americans and contributed to blighted inner city neighborhoods. Social work 
as a profession was not geared to address these structural issues and continued to use the casework model which was popular at the time.

Systems theory, family therapy, and the ecological systems perspective were pushed by many in the profession (Hopps \& Lowe, 2012). Ego psychology was followed by object relations theory which enhanced and provided greater depth to the understanding of the relational dynamic that occurred between worker and client and provided social workers with greater appreciation of the multi-layers of the social worker/client relationship (Blanck \& Blanck, 1974; Blanck \& Blanck, 1979; Bowlby, 1969; Edward, Ruskin, \& Turrini, 1981; Kernberg, 1975, 1976; Mahler, Pine, \& Bergman, 1975; Masterson, 1976; Tolpin, 1972; Winnicott, 1965). During the 1970s, Heinz Kohut (1971) launched self psychology which focused on disorders of the self and provided the profession with concepts such as mirroring, idealization of others, and twinship.

As the 1980s came to a close, researchers began to understand the relationship between the brain and the mind. As explained by Siegel (1999), "the mind develops at the interface of neurophysiological processes and interpersonal relationships" (p. 21). Understanding the brain can facilitate change at a bio-psychological level in the right brain hemisphere where emotional experiences are processed to include non-verbal communication such as touch, tone of voice, gestures, etc. (Applegate \& Shapiro, 2005; Perry, 2006).

Weick, Rapp, Sullivan, and Kisthardt (1989) were the first to generate the concept "strengths perspective." These authors offered that a focus on clients' strengths would better engage and support clients' growth. In The Strengths Perspective in Social Work Practice (Saleebey, 1992), several authors explained, in detail, the theoretical underpinnings of strengths based practice, especially in one's work with diverse, at-risk populations, and, in so doing, helped to move social work from a problem-focused-deficit model to a view that emphasized strengths, capabilities, and resilience.

Evidence-based practice (EDP) was formally introduced in 1992 with a focus on the medical profession which later crossed over to other professions, including social work. It should be noted however, that practice evaluation and accountability was by no means new to the field which was challenged with the push for evidence since the late 1960s (Sze \& Hopps, 1973, 1978).

As seen from the underpinning theories above, social casework was the dominant thrust of the profession for years, and there was limited attention to content that focused on how environmental factors impacted the client's daily functioning let alone how to affect change in the environment. The theories, as effective as they were thought to have been for individual change, did little to address questions related to client empowerment, structural inequality and/or institutional racism (Austin, 2000; Hopps, Pinderhughes, \& Shankar, 1995; Solomon, 1976). Moreover, there was not sufficient awareness of the impact of Freudian theories as related to the changing roles of women, many now educated and work place savvy since the late 1800's and certainly after two World Wars.

Similarly, the resentment of Black military personnel who had fought so bravely in segregated units was growing deeper and not well noticed by the country or the 
profession. Several had gone to school and college using the GI Bill. They went into the professions, moving away from farming, and several became teachers, physicians, morticians and attorneys. They told stories about the war, the Battle of the Bulge, the great Tuskegee Airmen. They expressed wariness relative to the slow road to equal rights. A new rhetoric was growing: Why would we wait so long for rights? Freedom? Students listened to their teachers, their preachers, their doctors.

Moreover, there was minimal attention to race related issues and/or race relations. Poverty, discrimination and legal oppression persisted. Jim Crow laws that were so strong in the early $20^{\text {th }}$ century were overlooked and unchallenged even when they were a central component of the structure and organization of social welfare and the delivery of social work services. For example, we witnessed that in some agency settings, white social workers could serve all clients while Black social workers could only serve Black clients. The Atlanta University School of Social Work had block placements so that second year MSW students were not limited to field experiences in segregated agencies in Atlanta and the southern region where case assignments were made on the basis of race (Bowles \& Hopps, personal observations).

\section{The Profession and the Poor}

It was the 1960s Civil Rights Movement and civil unrest, aided by Michael Harrington's (1962), The Other America, which highlighted the persistence of poverty in the country and challenged the supremacy of the casework mantra. The profession had to make accommodations to serve the poor and acknowledge discrimination, forcing it to examine its positive affinity for services to the middle class - those who were verbal, those who could come for an office appointment, those who could keep scheduled appointments, those deemed capable of developing insight about their problems, etc. The profession was confronted to think back to its founding mission and concern for the real poor. African-American protest, based on the denial of rights and discriminatory practices, introduced this new era of civil rights protests and later civil unrest during the Kennedy/Johnson years. The rights protests, the assassinations of President Kennedy and the killing of a number of civil rights workers, led to the passage of the 1964 Civil Rights Act which outlawed discrimination against racial, ethnic, national and religious minorities and women, and the 1965 Voting Rights Act which outlawed unfair voter registration laws imposed on Blacks. In a brief period, racial barriers in public facilities, the workplace and the ballot box were struck down by law. These new laws were enacted ten years after Brown v. Board of Education (1954), the Supreme Court ruling that struck down school segregation. Prior to Brown v. Board of Education (1954), the law of the land was separate but equal as set forth in Plessy v. Ferguson in 1896, but the practice was separate and unequal. White resistance to the 1954 landmark Supreme Court ruling of Brown v. Board of Education was unbelievably strong. To wit, 19 Senators and 81 Representatives from the South, including all of Georgia's congressional delegation, signed the Southern Manifesto, which re-enforced segregation in political ideology and discourse. The Southern Manifesto on Integration, signed in March 1956 to counter and defy the Brown v. Board of Education ruling read in part as follows: 
We regard the decision of the Supreme Court in the school cases as a clear abuse of judicial power. It climaxes a trend in the Federal judiciary undertaking to legislate, in derogation of the authority of Congress, and to encroach upon the reserved rights of the States and the people. . . It is destroying the amicable relations between the white and Negro races that have been created through 90 years of patient effort by the good people of both races. . . We pledge ourselves to use all means to bring about a reversal of this decision which is contrary to the Constitution and to prevent the use of force in its implementation (Southern Manifesto on Integration, 1956).

Owing to the lawmakers' recalcitrance, the desegregation of schools reached a stand still until 1957 when it became necessary for the federal government to intervene in the Little Rock Central High School case to uphold Brown v. Board of Education and allow nine children, who had been subjected to abuse, to enroll. The protests of the 1960 s were mostly peaceful; however, there had been growing tensions, especially since World War II, over entrenched inequality and the inability of the social structure to effectively respond to demands for change, voiced by activists, a growing number of whom were young people.

Hundreds of riots in the Freedom Summer of 1964, the "long hot summer" of 1967, and the tumultuous years of 1970-71, brought attention to entrenched poverty and a panoply of ills, including unemployment, poor housing, inadequate education, and lack of health care including maternal and child health and needs of the elderly. On July 28, 1967, President Lyndon Baines Johnson formed an 11-member National Advisory Commission on Civil Disorder to examine and explain the riots that plagued major cities. The Commission's 1968 report, known as the Kerner Report, concluded that the nation was "moving toward two societies, one black, one white - separate but unequal." The Report affirmed that discrimination and segregation that had permeated much of American life, threatened the country's future and unless conditions were remedied, the country faced a "system of "apartheid"” in major cities. The Report further stated:

"What white Americans have never fully understood but what the Negro can never forget - is that white society is deeply implicated in the ghetto. White institutions created it, white institutions maintain it, and white society condones it." (National Advisory Commission on Civil Disorders, 1968, p. 1)

The Report firmly implored the country to deal with its unfinished business and "make good the promises of American democracy to all citizens-urban and rural, white and black, Spanish-surname, American Indian, and every minority group" (National Advisory Commission on Civil Disorders, 1968, p. 2).

Many college and graduate students, some of whom were social workers, participated in peaceful civil rights demonstrations and marches along with mental health professionals, ministers, and community persons of all ethnic and racial groups. In fact, the authors observed that hundreds of persons who applied for and were accepted into social work programs during this time, participated in these civil rights protests and entered the profession so that they could become "change agents." 
The Black Power Movement came to the fore shortly after Dr. King's assassination in 1968, when more militant Blacks took over the leadership of the Student Non-Violent Coordinating Committee. Although the Civil Rights Movement, led by Dr. King, was guided by the teachings of Gandhi, non-violence Christian theology, and the social gospel, the Black Power Movement was largely guided by the work of Malcolm X, who argued the need for organizations to push for liberation and political and economic power based on Black separatism (Day, 2009). The Movement became increasingly more militant, and in the process, lost some middle class support across racial lines. Dr. King was missed.

During this time period, as in others, over eighty eight percent $(88 \%)$ of students who applied to schools of social work selected the casework track as opposed to fewer than five percent $(5 \%)$ who selected that of community organization (Morris, 2000). Those students who selected the community organization track were interested in ways in which they could use advocacy and community action to bring about needed structural changes in the environment for People of Color, the poor, and the oppressed. The Economic Opportunity Act (EOA) of 1964 required that Community Action Agencies (CAAs) be established to run Community Action Programs (CAPs). CAPS were developed to advocate for the poor who faced discrimination in employment, service delivery from social agencies that were receiving federal funds, to build and expand Head Start and accelerate the re-building of older urban communities. Funds were allocated directly to local grassroots organizations, passing over established agencies as well as city halls. This would not last long. Maximum Feasible Participation of the poor as prescribed in the Economic Opportunity Act was subsequently described as Maximum Feasible Misunderstanding (Moynihan, 1969). Nevertheless, there was growth in community organizations, aided by CAAS and CAPS, some taking on a more aggressive posture, drawing on the organizing methods used by Saul Alinsky in the 1930s and 40s behind the stock yards in Chicago (Hopps \& Lowe, 2012). Growing recognition of the need for structural change and community based advocacy brought renewed attention to macro interventions, especially community organization but also community development, social planning and policy and their value within the profession and in poor communities.

Mobilization for Youth, the New York demonstration project funded by private foundations and federal government agencies, particularly the National Institute of Mental Health, generated theories and intervention strategies for examining urban reform and changing democratic processes that influenced the design of the War on Poverty. The Model Cities Program followed the War on Poverty in the late 1960s and both were signature programs of the Johnson administration's Great Society. The Fair Housing Act was passed in 1968 striking at discrimination in that domain and adding more teeth to anti-discrimination and civil rights laws passed earlier in 1964 and 1965.

An important facet of professional activity included opening up opportunities for Blacks and other People of Color to pursue professional education and also the establishment of many new schools of social work to serve the newly discovered poor, needful population, along with the middle class (Memorandum from Jo Ann Regan, Director, Office of SW Accreditation, CSWE, September, 2013). These new schools with their influx of students changed the social work demographic. Over $20 \%$ of enrolled 
students were People of Color, a major shift in the profession. Student activists, many of whom were students of color, pushed for a more relevant curriculum and diverse faculty. Some professors made alliances with the poor and found pathways to help change the social work academic establishment (Schiele \& Hopps, 2009). Federal funding became more available to schools of social work after World War II and had influence on the curriculum, funding for faculty and financial aid to students. In fact, the development of baccalaureate social work programs in public institutions, funded by federal agencies, provided access to a more racially and socio-economically diverse cohort of students (Austin, 2000). Following formal approval by CSWE in 1974 of a set of accreditation standards for baccalaureate social work programs, the number of BSW programs grew dramatically during the next decade and beyond. In its most recent statistics, CSWE (2013) reports that the number of accredited BSW programs more than doubled that of accredited MSW programs - 489 vs. 227. The baccalaureate programs became entry ports for Blacks, other people of color as well as those from lower socio-economic classes.

The students looked different from earlier periods. Despite a continued preponderance of women, there was clearly much greater diversity within the student body in most programs. This increased diversity was fueled in part by an infusion of federal funding from the National Institute of Mental Health (NIMH) which also helped accelerate the growth in the number of accredited BSW programs. Federal funding also provided resources for graduate education at both the master's and doctoral levels (Austin, 2000). Federal funding for social work was important and continued during the Kennedy, Johnson, Nixon administrations, but became more limited under Carter and was drastically curtailed under Reagan and Bush (Austin, 2000; Day \& Schiele, 2013; Hopps, 2000; Morris, 2000). Reagan's philosophy towards the social work establishment and clients was guided not only by conservatism but also by right wing ideology; the administration's tone toward the poor and sexual minorities was harsh, for example demeaning commentary about the "welfare queen and the Cadillac."

Although President "Bill" (William J.) Clinton voiced different sentiments about the poor and seemed to understand structural and institutional causation, he followed much of the Reagan/Bush ideology of laissez-faire civil rights and demolition of social welfare and particularly "ending welfare as we know it." (Day \& Scheile, 2013). George W. Bush moved back to the Reagan philosophy although advocating a softer conservatism he characterized as "compassionate conservatism." The George W. Bush legacy toward the poor is undoubtedly reflected in the debacle that surrounded the delivery of emergency relief services after Hurricane Katrina. In effect, the "golden age" of funding for social welfare and its professional arm, social work, slowly morphed into one of resource constriction. This pattern, started under Carter, is apparent even in President Obama's signature domestic achievement, The Patient Protection and Affordable Care Act (PPACA) signed into law on March 23, 2010. While this law does create new opportunities within the healthcare domain, there are no funds specifically allocated for social work education with respect to the profession's role in the delivery of health care services. 
Today, there are no grassroots groups pushing the profession toward greater progressivism as there were in the late 1960s. During this prior period, the major welfare organizations focused on the poor and their rights. The National Welfare Rights Organization (NWR0) was led by a chemist, the late Dr. George Wiley, not a social worker or cognate professional. Nevertheless, the group was forceful, maybe even militant in pushing established agencies and public welfare offices to better serve the poor, granting them their lawful benefits. Frances Fox Piven (New York University) and Bill Cloward (Columbia University School of Social Work) became known for providing much of the theoretical orientation for the expanded direct participation of the poor in activism for greater access to social services, including voter registration.

Sensing a need for a collective voice and action, a group of Black social workers convened in San Francisco, California on May 8, 1968 to establish a national social work organization that would advocate for and address social issues and concerns of the Black community. The group formed the National Association of Black Social Workers (NABSW) and put pressure on the National Conference of Social Welfare (NCSW), the National Association of Social Work (NASW), and the Council on Social Work Education (CSWE) to increase the number of persons of African ancestry to serve on various committees and hold office in these organizations. NABSW also emphasized the need for accountability of social welfare systems serving Black families as well as the development of service delivery strategies that would better serve Black communities. The organization also pressured CSWE to live up to the mission of the profession by examining content in the social work curricula so that it would become less Euro-centric and more accurately reflect the Black experience and that of other People of Color, the poor and oppressed, as well as the forces that supported structural inequality.

Schools of social work were also pressured to add persons of African descent to their faculties. Once in rank, new Black faculty members, though few in number, added their voices to the importance and need for greater and non-stereotypical content on racial and ethnic groups. In the second special edition of Social Work, focused on people of color, entitled Racial and Ethnic Minorities, it was reported that some eighty-nine articles were published between 1960 and 1975 that addressed "race relevant questions" (Schiele \& Hopps, 2009). Prior to the earlier special edition of social work entitled People of Color (Hopps, 1982), the profession had evidenced some concern about issues relevant to people of color and the articles were generally referred to as "the Negro Problem;" and from 1969 to 1975, as "the Black Phenomenon"(Schiele \& Hopps, 2009).

NABSW held its first annual conference in Philadelphia in 1969. The theme was "The Black Family" in response to the Moynihan Report on the disintegration of the Negro family as the cause of lower socio-economic status and the limits of government intervention for positive change unless Negroes took more responsibility for self improvement. The Moynihan Report, delivered in a speech by President Johnson at Howard University on June 4, 1965, had stirred controversy among those in the civil rights movement because it seemed to place blame for family formation and lifestyle, poverty and unemployment on individual choices which were greatly limited due to the economy. There was not sufficient weight given to structural inequality. Opposition literature, from Blacks and other scholars, evolved and grew with the intent of showing 
the strengths of oppressed Blacks in the face of intractable structural discrimination and inequality. One prominent contributor to this debate was Robert Hill (1972) whose book, The Strengths of Black Families, was in direct response to the Moynihan Report.

Several African-Americans who entered social work education in the 1960s-1970s found a way to move up in academe becoming tenured professors, deans, associate provosts and provosts. Many also became key administrators and executive directors of national organizations. Although there was generally a positive response from the profession, albeit a slow one, it was not without controversy and competition from those in power, mostly privileged males and those wishing power, mostly privileged females. The change strategies and arguments here were not unrelated to those which informed and influenced all of the subsequent movements.

\section{The Movements: Women, Sexual Orientation and Gender Expression}

The first era of the women's movement was in the 1800s and focused on women's suffrage, the right of women to vote, and abolition. Day (2013) observed that Women, although not owned were:

almost treated like Negro slaves inside and outside the home. Both were expected to behave with deference and obedience towards owner or husband; both did not exist officially under the law; both had few rights and little education; both found it difficult to run away; both worked for their masters without pay; both had to breed on command and to nurse the results (p. 183).

The first phase of the feminist movement occurred during the 1940s and continued through the 1950s, advancing the "suffrage" theme. The publication of Betty Friedan's (1963) classic treatise on The Feminine Mystique heralded the onset of a second era in the women's movement during which the primary focus shifted to issues of social and cultural concerns. The book sought to awaken the conscience of middle class American women whose roles in society were limited mostly based on gender. Friedan, a 1942 graduate of Smith College, based her book on survey data from Smith College alumnae, Class of 1942 for their $15^{\text {th }}$ college reunion in 1957. Her systematic survey showed that many of her classmates were unhappy, felt entrapped and that their ambitions were thwarted despite living in material comfort. This prompted her to conduct interviews with other suburban housewives which led to the publication of The Feminine Mystique. How many Black, Hispanic, Native American or Eastern European women do we suppose were included in the study? We know that many of these women were in the workforce, and without choice.

Another feminist activist and Smith College graduate, Class of 1956, Gloria Steinem, helped create Ms. Magazine in 1971 which provided a sounding board for the voices of contemporary women. The Feminist Movement was criticized by many Black Women who voiced that the movement represented the viewpoint of white, middle-class, educated women and ignored or marginalized the voices and lived experiences of other women. Some Black feminists argued that sexism, class, oppression, and racism were inextricably bound; hence, Black women experienced a different and more intense kind of oppression from that of white women. In short, Black feminists felt that white 
feminists minimized or ignored oppression based on race and class thereby marginalizing and excluding them from the "Movement." Some Black feminists thought that white feminists even colluded with their men - their fathers, husbands, brothers, uncles and sons - and therefore held "deferred power" (Hopps, 1982).

Black women had a long history of self-help, social activism and "race uplift." In fact, self help organizations date back to the late 1700s and were active at the local level where Black women provided extensive mutual aid assistance. This continued until the 1890 s as a more political agenda evolved focusing on suffrage and anti-lynching. The National Association of Colored Women was founded in 1896, only three decades after the Civil War, pre-dating the founding of the National Association for the Advancement of Colored People (NAACP) by some fifteen years. (It is well to be mindful of the roles of Jane Adams and W. E. B. DuBois in this historic development that began with discussions at Henry Street Settlement in New York City). Equally important was W. E. B. DuBois leaving the Progressives and Jane Addams when she did not support suffrage for Blacks. Race "up-lift" work required Black women to be politically savvy in relation to Black men.

Since race progress was conventionally defined as male dominance and distinction not only within the family, but also within such masculine domains as politics, the market, and the military. Black women's public activities, independence, and leadership were controversial within uplift ideology insofar as they departed from the only legitimate realm for Black women's activity, their reproductive capacity within patriarchal Black families (Gaines, 1996, p. 42).

The social situation of Black women corresponded with that of white women but with the added forces of racism and economic and social disadvantage. Both populations of women had a political struggle, but Black women's struggle was so much harsher owing to race and economics. The feminist agenda was not viewed as inclusive. Although Black women did not begrudge the quest by white women for advancement, they were stunned when some white women did not understand the gravity of racism, historical economic and social disadvantage and the need for affirmative social justice.

A few Black women in the profession did move up. There seemed to have been a convergence among lesbian women who would "coalesce," supporting and advocating for one another for faculty and decanal positions as well as executive positions in professional organizations. Their affiliation and orientation seemed more powerful than race, class or social background. Although they may have identified with oppressed people, and many did, this perspective became moot in instances where there was competition with an oppressed person for positions of power they sought.

In response to the feminist movement, a more economically diverse group of women began to demand affordable child care, birth control and the creation of rape crisis and domestic violence centers which could serve as places where their sisters might be helped to deal with the abuses they received in safe environments. Research in these areas by social workers and other mental health professionals emerged. Significant contributions included the Boston Women's Health Book Collective, Women and their Bodies (1970), Our Bodies, Ourselves (1971), and others that have continued to proliferate. Many of 
these more recent contributions also include content relevant to the needs of pre-teen and adolescent girls and boys. Much of this content found its way into the social work curriculum; however, was there content on eugenics which was experienced by severely oppressed women, often in prison? At issue was whether the curriculum lagged behind the practice environment. Women students began exposing and teaching faculty about issues relevant to their reality related to growth and development including women's health, rape, and domestic violence. Similarly, Black students and poor people exposed and taught the faculty about their reality encompassing race, discrimination, and poverty.

Gay liberation became an active issue in the profession during the 70s and 80s. This population drew upon First Amendment rights and the Civil Rights Act of 1964. The Lambda Defense and Education Fund was active in the pursuit of civil rights for gays and lesbians in employment, child custody, and education paying for legal representation and developing a network of legal experts. The work of this fund was aided significantly by the National Gay and Lesbian Task Force and was the major mover of the March on Washington for Lesbian and Gay rights in 1979. Gains for same sex persons include the repeal of existing sodomy laws as well as repeal of the "Don't Ask Don't Tell" policy on September 20, 2011 by President Obama. The "Don't Ask Don't Tell" policy was adopted by the Clinton administration and prohibited same sex persons from disclosure of their sexual orientation while serving in the U. S. military.

On June 26, 2013, the Supreme Court, by a vote of 5 - 4 ruled unconstitutional a 1996 law denying federal benefits to legally married same-sex couples and permitted gay marriage in California which increased to 13 the number of states that allow for same sex marriage. Ironically, the day before GLBT Rights advocates celebrated this land mark 5 to 4 Supreme Court reversal, the same court deemed as unconstitutional Section 4 of the 1965 Voting Rights Act. This ruling cut at the very core of the Voting Rights Act leaving it to a divided Congress to redefine criteria to determine which states need preclearance by the Justice Department for electoral changes. Obviously, in this instance there was no celebrating among people of color and liberal pundits.

Earlier in this paper, we noted the deaths of civil rights advocates. It is similarly important to reflect, as we and other professionals did, on the deaths of:

- San Francisco Board Supervisor, Harvey Milk and Mayor George Moscone, both of whom were gay, in 1978 by Dan White another City supervisor who had resigned his job and wanted it back;

- Matthew Shepard, a white gay student, near Laramie, Wyoming by 3 white men; and

- James Byrd, Jr., a Black man tied to a truck by 2 white supremacists and decapitated in Jasper, Texas in 1998.

The latter two deaths resulted in the passage of the Matthew Shepard and James Byrd, Jr. Hate Crimes Prevention Act, the country's first Hate Crime Bill that was signed into law by President Barack Obama on October 28, 2009. This was an amazing feat since the 3445 lynchings in the $19^{\text {th }}$ and $20^{\text {th }}$ centuries did not result in the passage of a national anti-lynching law. Now hate groups, including the Aryan Nation, are increasing 
and there is growing concern by members of the profession over angry white people, especially males.

\section{New Faculty, New Theorists}

Prominent new social work theorists came to the forefront starting in the 1960s, many of whom were women of color whose writings added authenticity, thick context and fresh perspectives (See, 2002): Elaine Pinderhughes, Barbara Solomon, Deloris Norton, Harriette McAdoo, Rosina Bacerra, Joyce Ladner, Jewel Taylor Gibbs, Wynetta Devore, Martha Ozzawa, among others. There were also men of color who made contributions: Leon Chestang, Robert Hill, Lawrence Gary, Andrew Billingsley, Harry Aponte, Juan Longress, Brig Mohan, Julio Morales, and Wade Nobles, among others. Black psychiatrists such as James Comer, Alvin Poussaint, William Grier and Price Cobbs also added to the body of knowledge that was used by the profession. It was after the assassination of Dr. King and the subsequent riots that Grier and Cobbs (1968) wrote Black rage which described the insidious effects and psychic stresses Black people experienced in response to slavery, Jim Crow and discrimination which was the basis of their anger and rage. John Turner became the first African American editor-in-chief of the Encyclopedia of Social Work and June Gary Hopps became the first African American named editor-in-chief of Social Work, the profession's flagship journal. Others also added scholarship helping to advance theory and practice about people of color and race (for example, Carol Stack, Monica McGoldrick, Effie Schlesinger and Jeane Giovanni).

\section{The CSWE Curriculum Standards: Mission Driven or Mission Drift?}

The Council on Social Work Education Curriculum Policy Statements did not include the need for the study of oppression and injustice in the curricula of schools of social work until 1983. There was no mention of the concepts of oppression and social justice in the CSWE Curriculum Policy Statements of 1952, 1962 and 1969, "although they noted links between destructive social and economic conditions and the problems that motivate people to seek help" (Gil, 1995, p. 258). The 1982 Curriculum Policy Statement is the first to make reference to the promotion of "social and economic justice" and that "social workers hold that people should have equal access to resources, services and opportunities." Under the heading "Special Populations," the 1982 Policy Statement noted that "the profession has also been concerned about the consequences of oppression and that the "curricula must give explicit attention to the patterns and consequences of discrimination and oppression" (Gil, 1995, p. 258). The "1992 revision of the CSWE Curriculum Policy Statement is clearer than the 1982 statement concerning oppression and injustice," and stresses that schools of social work have the responsibility to teach about social justice and approaches to overcome oppression. However, like the 1982 policy statement, the 1992 revision reflects the fallacious assumption that discrimination, oppression, and injustice affecting women, minorities and other discrete social groups can be overcome without eradicating their sources in the occupational and social class divisions of contemporary capitalism" (Gil, 1995, pp. 258-59). The 1992 CSWE draft Curriculum Policy statement did not include material on poverty and the poor. The issue 
was debated and later added. Could this critical issue have been the result of a simple oversight? Not likely! Within the context of the heated debate that engulfed it, one of the profession's highly respected thinkers asked in a provocative co-authored work, Unfaithful Angels: How Social Work has Abandoned its Mission, if the profession had indeed abandoned its mission to the poor and drifted to a psychodynamic orientation (Specht \& Courtney, 1994; Haynes \& Mickelson, 1986).

Obviously, it was a long, hard path from earlier Educational Policy Accreditation Standards (EPAS) to the Standards for 2001 and 2008 where programs are expected to attend to diversity in both the explicit and implicit curricula. The most recent 2008 EPAS recognizes that the education of social work students extends beyond the classroom and field internship; hence elements such as the program and institutional policies, faculty, student resources and activities that impact students must be addressed. The movement to diversity, representing all groups who claim oppression, is not without considerable debate. The question is: When all are considered oppressed, is anyone oppressed?

Although the 2008 curriculum statement moved social work to a competency-based outcomes approach, and includes Educational Policy 2.1.4 - Engage diversity and difference in practice - the question raised at the beginning of this discussion around a framework (see Maguire, 1980) for determining which groups are so disadvantaged that they need preference, based on the four conditions set forth, is still relevant. It seems that what the profession has to do now is step back and debate the components of this framework, starting with the premise that if available "alternatives to enforced preferences" have not worked, then why? Harvard Law Professor Derrick A. Bell (1980) asserts in his theory of "interest convergence" that Black rights are recognized and protected only when it advances the interest of whites. He further asserts that "white institutions have not historically advanced the interests of African Americans through integration or inclusion without accruing equal or greater benefit to themselves or their interest in the process" $(1980$, p. 526). Hence, an emphasis on diversity lessens or negates the more challenging issues of race and class inequality. Bell clarifies this by focusing on Affirmative Action, a construct that many whites interpret to mean diversity policies designed to benefit white students rather than a means of benefitting those who have been negatively impacted by skin color, Jim Crow and the insidious culture of discrimination that pervades in this country. Hence, the word diversity, and not the words race and class, is more comfortable to whites because, in the narrow way in which they construe it, they inevitably become the unwitting beneficiaries. Rather than using the word diversity, it may be important to use the words race and class so that those who have been most marginalized in society also gain benefits. Additionally, it speaks to the reality of what has occurred in this country, i.e., the country has been engaged in a conflict about race and class, not a conflict about diversity. Thus, society's propensity to focus on the more benign notion of diversity may actually be serving as a diversion with respect to the achievement of the more substantive (albeit controversial and ideal) goal of racial justice on which this country is founded and which we, as Americans, seek to achieve. (Bell, 1980; Daniels \& Van Patterson, 2012). 


\section{References}

Applegate, J. S., \& Shapiro, J. R. (2005). Neurobiology for clinical social work: Theory and practice. New York, NY: W. W. Norton and Co., Inc.

Austin, D. M. (2000). Greeting the second century: A forward look from a historical perspective. In J. G. Hopps \& R. Morris (Eds.), Social work at the millennium: Critical reflections on the future of the profession (pp. 18-41). New York, NY: The Free Press.

Bell, D. (1980). Brown v. Board of Education and the interest-convergence dilemma. Harvard Law Review, 93(3), 518-533.

Biester, F. P. (1957). The casework relationship. Chicago, IL: Loyola University Press.

Blanck, G, \& Blanck, R. (1974). Ego psychology theory and practice. New York, NY: Columbia University Press.

Blanck G., \& Blanck, R. (1979). Ego psychology II. New York, NY: Columbia University Press.

Boston Women's Health Book Collective. (1970). Women and their bodies. Boston, MA: New England Free Press.

Boston Women's Health Book Collective. (1971). Our bodies, ourselves. Boston, MA: New England Free Press.

Bowlby, J. (1969). Attachment and loss. Vol. I: Attachment. New York, NY: Basic Books.

Clayton, O. (1996). The Church and social change: Accommodation, moderation, or protest. In O. Clayton (Ed.), An American dilemma revisited: Race relations in a changing world (pp. 191-200). New York, NY: Russell Sage.

Council on Social Work Education. (2103). CSWE Statistical Report. Retrieved from http://www.cswe.org/Accreditation.aspx

Daniels, M., \& Van Patterson, C. (2012). Symposium: Civil Rights or Civil Wants? Reconsidering race in the desegregation of higher education. Georgia Law Review, 46(3), 521-556.

Day, P. J. (2002). A new history of social welfare. New York, NY: Pearson.

Day, P. J. (2009). A new history of social welfare (6 ${ }^{\text {th }}$ ed.). New York, NY: Pearson.

Day, P. J., with Schiele, J. H. (2013). A new history of social welfare $\left(7^{\text {th }}\right.$ ed.) New York, NY: Pearson.

DuBois, W. E. B. (1903). The souls of Black Folk. Chicago, IL: A. C. McClurg.

Edward, J., Ruskin, N., \& Turrini, P. (1981). Separation-individuation: Theory and application. New York, NY: Gardiner Press, Inc 
Freud, A. (1936). The ego and the mechanisms of defense: The writings of Anna Freud. New York, NY: International Universities Press.

Friedan, B. (1963). The feminine mystique. New York, NY: W. W. Norton \& Co.

Friedman, D., \& Maggs, J. (2008, August 27). Authorities play down plot against Obama. Government Executive. Retrieved from http://www.govexec.com/defense/2008/08/authorities-play-down-plot-againstobama/27545/

Gaines, K. K. (1996). Uplifting the race: Black leadership, politics and culture in the twentieth century. Chapel Hill, NC: The University Press of North Carolina Press.

Garrett, A. M. (1942). Interviewing, its principles and methods. New York, NY: Family Welfare Association of America.

Gil, D. (1995), Confronting social injustice and oppression. In F. G. Reamer (Ed.), The foundation of social work knowledge (pp. 231-263). New York, NY: Columbia University Press.

Grier, W., \& Cobbs, P. (1968). Black rage. New York, NY: Basic Books.

Harrington, M. (1962). The other America. New York, NY: Macmillan Press.

Hartmann, H. (1958). Ego psychology and the problem of adaptation. New York, NY: International Universities Press.

Haynes, K. S., \& Mickelson, J. S. (1986). Affecting change: Social workers in the political arena. Boston, MA: Allyn \& Bacon.

Hill, R. B. (1972). The strengths of Black families. New York, NY: Emerson Hall Publishers.

Hollis. F. (1949). The techniques of casework. Journal of Social Case Work, 30 (June), 235-244.

Hollis, F. (1965). Casework and social class. Social Casework, 46, 463-471.

Hopps, J. G. (1982). Oppression based on color. Social Work, 27(1), 3-5.

Hopps, J. G., \& Lowe, T. B. (2012). Social work practice in the new millennium. In C. Dulmus \& K.Sowers (Eds.), The profession of social work: Guided by history, led by evidence (pp. 51-90). New York, NY: John Wiley and Sons, Inc.

Hopps, J. G., Pinderhughes, E., \& Shanker, R. (1995). The power to care: Clinical practice effectiveness with overwhelmed clients. New York, NY: The Free Press.

Kernberg, O. F. (1975). Borderline conditions and pathological narcissism. New York, NY: Jason Aronson, Inc.

Kernberg, O. F. (1976). Object relations theory and clinical psychoanalysis. New York, NY: Jason Aronson, Inc. 
Kohut, H. (1971). The analysis of the self. New York, NY: International Universities Press.

Maguire, D. C. (1980). A new American justice. Garden City, NY: Doubleday \& Co.

Mahler, M. S., Pine, F., \& Bergman, A. (1975). The psychological birth of the human infant. New York, NY: Basic Books.

Masterson, J. F. (1976). Psychotherapy of the borderline adult: A developmental approach. New York, NY: Brunner/Mazel.

Morris, R. (2000). Social work practice in the new millennium. In C. Dulmus \& K. Sowers (Eds.), The profession of social work: Guided by history, led by evidence (pp. 42-70). New York, NY: John Wiley and Sons, Inc.

Moynihan, D. P. (1965). The Negro family: The case for national action. Washington, DC: United States Department of Labor.

Myrdal, G. (1944). An American dilemma: The Negro problem and modern democracy. New York, NY: Harper \& Brothers.

National Advisory Commission on Civil Disorders. (1968). Report of the National Advisory Commission on Civil Disorders: Summary of report. Retrieved from www.eisenhowerfoundation.org/docs/kerner.pdf

Parad, H. J. (1958). Ego psychology and dynamic casework. New York: Family Service Association of America.

Parad, H. J., \& Miller, R. R. (1963). Ego-oriented casework: Problems and perspectives. New York, NY: Family Service Association of America.

Perlman, H. H. (1979). Relationship, the heart of helping people. Chicago, IL: University of Chicago Press.

Perry, B. (2006). Applying principles of neurodevelopment to clinical work with maltreated and traumatized children: The neurosequential model therapeutics. In N. B. Webb (Ed.), Working with traumatized youth in child welfare (pp. 27-52). New York, NY: The Guilford Press.

Saleebey, D. (Ed.). (1992). The strengths perspective in social work practice. New York, NY: Longman.

Schiele, J. H., \& Hopps, J. G. (2009). Racial minorities then and now: The continuing significance of race. Social Work, 54(3), 195-199.

See, L. A. (2002). Human behavior in the social environment from an African-American perspective $\left(2^{\text {nd }}\right.$ ed.). Binghamton, NY: Hayworth Press, Inc.

Siegel, D. J. (1999). The developing mind: Toward a neurobiology of interpersonal experience. New York, NY: Guilford Press.

Solomon, B. B. (1976). Black empowerment: Social work in oppressed communities. New York, NY: Columbia University Press. 
Southern Manifesto on Integration. (1956). Retrieved from http://www.pbs.org/wnet/supremecourt/rights/sources_document2.html

Specht, H., \& Courtney, M. (1994). Unfaithful angels: How social work has abandoned its mission. New York, NY: The Free Press

Sze, W. C., \& Hopps, J. G. (1973). Evaluation and accountability in human service programs. Boston, MA: Schenkman Publications.

Sze, W. C., \& Hopps, J. G. (1978). Evaluation and accountability in human service programs $\left(2^{\text {nd }}\right.$ ed.). Boston, MA: Schenkman Publications.

Tolpin, M. (1972). On the beginnings of a cohesive self. The Psychoanalytic Study of the Child, 26, 317-352.

Transnational Racial Justice Initiative. (2001). The persistence of White Privilege and institutional racism in US Policy: A report on U.S. Government compliance with the International Convention on the Elimination of all forms of Racial Discrimination. Compiled by Transnational Racial Justice Initiative, March, 2001,

Weick, A., Rapp, C., Sullivan, W. P., \& Kirsthardt, W. (1989). A strengths perspective for social work practice. Social Work, 34, 350-354.

Winnicott, D. W. (1965). The maturational processes and the facilitating environment: Studies in the theory of emotional development. New York, NY: International Universities Press.

\section{Author note}

Address correspondence to: Dorcas Davis Bowles, MSW, Ed.D., Distinguished Scholar of Social Work, Dept. of Social Work and Human Services, 1000 Chastain Road, Kennesaw, GA 30144-5591. Email: dbowles3@kennesaw.edu

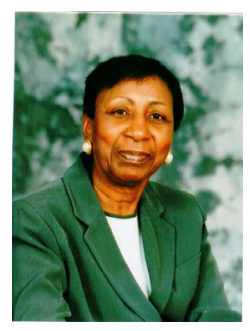

Dorcas Davis Bowles serves as Distinguished Scholar of Social Work at Kennesaw State University, Kennesaw, GA. Earlier, she served as Assoc. and Interim Dean, Smith College School for Social Work; Dean, University of Texas at Arlington School of Social work; Dean, Clark Atlanta University School of Social Work, and Provost and Vice President of Academic Affairs at Clark Atlanta. She has published several book chapters and articles and received the Distinguished Day Garrett Award from Smith College School for Social Work.

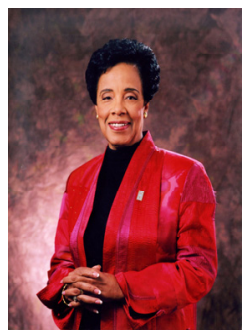

June Gary Hopps is The Thomas "Jim" Parham Professor at the School of Social Work, University of Georgia and Dean and Professor Emerita, Boston College School of Social Work. She has served as Editor-in-Chief, Social Work; Associate Editor-in-Chief, Encyclopedia of Social Work $\left(19^{\text {th }}\right.$ ed.). She has authored/co-authored six books and numerous articles. She also served as Chair of the Board, Spelman College and Board Member, Wheelock College. She is the recipient of numerous awards, including several from NASW which inducted her into the Pioneer Society in 2013. 